\title{
Comparative Beneficiation Study of Gyel Columbite Ore Using Double Stage (Magnetic-to-Magnetic and Magnetic-to-Gravity) Separation Techniques
}

\author{
Oladunni Oyelola Alabi ${ }^{*}$, Shehu Aliyu Yaro², George Thomas Dungka², Ferdinand Asuke², \\ Binta Hassan1 \\ ${ }^{1}$ National Metallurgical Development Centre, Jos, Nigeria \\ ${ }^{2}$ Metallurgical and Materials Engineering Department, Ahmadu Bello University, Zaria, Nigeria \\ Email: "oladunni69alabi@yahoo.com
}

Received 21 January 2016; accepted 28 March 2016; published 31 March 2016

Copyright (C) 2016 by authors and Scientific Research Publishing Inc.

This work is licensed under the Creative Commons Attribution International License (CC BY). http://creativecommons.org/licenses/by/4.0/

\section{c) (i) Open Access}

\section{Abstract}

The comparative beneficiation study of Gyel columbite ore using double stage (magnetic-to-magnetic and magnetic-to-gravity), located in the vicinity of Gyel village in Jos South Local Government Area of Plateau State to metallurgical grade was carried out. The ore sample was sourced from 20 different pits each $1.5 \times 1.5 \times 2$ meters deep, 50 meter apart covering a land of 50 hectares. The samples from the 20 pits were crushed, pulverized and homogenized. $200 \mathrm{~kg}$ of the homogenized ore sample was used for the experiment and laboratory works. Chemical characterization of the ore sample was carried out using energy dispersive X-ray fluorescence spectrometer (ED-XFR). Single and double stage concentration tests using magnetic and gravity methods were carried out respectively. The results of the chemical analysis of ore sample reveal that, Pit 1 contains $12.26 \%$ $\mathrm{Nb}_{2} \mathrm{O}_{5}, 21.6 \% \mathrm{Fe}_{2} \mathrm{O}_{3}, 36.1 \% \mathrm{SiO}_{2}$; Pit 20 contains $4.78 \% \mathrm{Nb}_{2} \mathrm{O}_{5}, 19.34 \% \mathrm{Fe}_{2} \mathrm{O}_{3}, 23.96 \% \mathrm{SiO}_{2}$ and the homogenized sample contains $6.71 \% \mathrm{Nb}_{2} \mathrm{O}_{5}, 23.1 \% \mathrm{Fe}_{2} \mathrm{O}_{3}$ and $27.0 \% \mathrm{SiO}_{2}$ averagely. The liberation study reveals that the niobium of ore can be liberated over a range of sieve size fractions of $-355+63 \mu \mathrm{m}$ for the coarse and $-63+45 \mu \mathrm{m}$ for the fine particle size fractions. On the basis of this, sieve size fractions of $-1400+355 \mu \mathrm{m}$ (as coarse size), $-355+90 \mu \mathrm{m}$ (as medium size) and $-90+45 \mu \mathrm{m}$ (as fine size) were used for the concentration tests. The concentration test using the double stage processes revealed that the air-floatation followed by rapid magnetic method produced a concentrate with the highest percent assay of $54.48 \% \mathrm{Nb}_{2} \mathrm{O}_{5}$ with a recovery of $96.53 \%$

\footnotetext{
${ }^{*}$ Corresponding author.

How to cite this paper: Alabi, O.O., Yaro, S.A., Dungka, G.T., Asuke, F. and Hassan, B. (2016) Comparative Beneficiation Study of Gyel Columbite Ore Using Double Stage (Magnetic-to-Magnetic and Magnetic-to-Gravity) Separation Techniques. Journal of Minerals and Materials Characterization and Engineering, 4, 181-193.
} 
followed by the rapid-to-rapid magnetic method which produced a concentrate assaying $\mathbf{5 2 . 1 2 \%}$ $\mathrm{Nb}_{2} \mathrm{O}_{5}$ with a recovery of $86.96 \%$. These results meet and surpass the $50 \% \mathrm{Nb}_{2} \mathrm{O}_{5}$ stipulated as the acceptable metallurgical grade concentrate for niobium metal production in the literature.

\section{Keywords}

Beneficiation, Gyel Columbite, Metallurgical Grade, Homogenization, Characterization

\section{Introduction}

Some industrial processes utilize particulates in some stage of their operations, perhaps as raw materials. Particles systems are especially important in mineral processing — a field that deals almost exclusively with particulates, from run-of-mines to final concentrates. The objective of mineral processing operation is to take an input stream of particles with a given set of characteristics, and separate the material into product streams, each with its own set of specific characteristics [1]. Magnetic, gravity and froth flotation are some of the major mineral processing techniques used in concentrating mineral from the low grade ore to a high grade concentrate and their principles are well established [2] [3].

Among the several methods of classifying minerals, minerals can be classified based on their magnetic properties of which paramagnetic minerals are attracted along the lines of magnetic forces to the point of greater intensity. Diamagnetic minerals are repelled along the lines of magnetic force to a point of lesser field intensity while ferromagnetic minerals are special category of paramagnetic minerals, having a very high susceptibility to magnetic forces and retain some magnetism after removal from the magnetic field [4]. The conventional available magnets are low intensity magnetic separators having flux density up to 2000 gauss which can separate ferromagnetic mineral such as iron. Separating paramagnetic or weekly magmatic particles require higher flux density used in removal or processing of weekly magnetic iron - bearing particles, e.g. columbite.

\section{Nigerian Columbite Ore Deposits}

Nigeria is one of the richest countries in the world mining columbite with a workable reserve estimated of 114,000 million tons [5] [6]. These deposits are widely distributed in places like Plateau, Nasarawa, Kogi, Gombe, Niger, Kaduna, Bauchi, etc. [7]. The mineral columbite has found wide application in ferrous-metallurgical industries as alloying element in steel making and also as strategic metal in the production of telecommunication and cell phones equipment. Thus, making the mineral expensive and scarce as its occurrence is rare in nature [5] [8]-[10].

Columbite contains oxide of niobium $\left(\mathrm{Nb}_{2} \mathrm{O}_{5}\right)$ and oxide of tantalum $\left(\mathrm{Ta}_{2} \mathrm{O}_{5}\right)$ in different proportions. When the proportion of niobium oxide is higher than the tantalum oxide, the mineral is called columbite $\{(\mathrm{Fe}, \mathrm{Mn})$ $\left.\mathrm{Nb}_{2} \mathrm{O}_{6}\right\}$, while it is called tantalite $\left\{(\mathrm{Fe}, \mathrm{Mn}) \mathrm{Ta}_{2} \mathrm{O}_{6}\right\}$, when the tantalum oxide content is higher compared to that of niobium [11] [12].

\section{Gyel Columbite Ore Deposit}

Gyel columbite deposit is located in Jos South Local Government Area of Plateau State, Nigeria. The left-over of millions of tons of the columbite and cassiterite mined at deposits across Jos in Plateau State by the British Miners in the late sixties are still very rich in the above mentioned minerals [6] [13]. In the past, when mining and processing of columbite and cassiterite were done at these mine fields, less attention was given to Gyel deposit probably because their processing methods were not well defined then or there was no enough time to research into the development of appropriate method of beneficiating the mineral from its deposit [14].

\section{Materials and Method}

\subsection{Materials}

$200 \mathrm{~kg}$ of the ore sample collected from 20 different pits of the Gyel mining site was harmonized and $5 \mathrm{~kg}$ of the 
ore sample was used in carrying out the research utilizing sieve size fractions of $-1400+355 \mu \mathrm{m},-355+90 \mu \mathrm{m}$ and $-90+45 \mu \mathrm{m}$.

\subsection{Equipment}

The equipment used in this research work were: three disc rapid magnetic separator, Kip Kelly air floating machine, head pans used as collectors, energy dispersive X-ray fluorescence spectrometer, sieves and Denver sieve shaking machine.

\subsection{Mineral Concentration Test}

The mineral concentration techniques used for this research were magnetic and gravity methods of concentration. The mineral concentration process was carried out in two (2) place. The first phase was the single stage test that involved the concentration of the ore sample using magnetic method and the pre-concentrate obtained serving as feed in the second stage process of using gravity method of air floatation. The products of the test were assayed for their mineral compositions. The stages are explained as follows.

\subsubsection{Phase I: Single Stage Separation Method}

1) Magnetic Concentration Method

Optimum Efficiency Dry High-Intensity Magnetic Separator (Three Disc Rapid Magnetic Separator) of the National Metallurgical Development Centre (NMDC), Jos. Model 4-3-15 OG was used in beneficiating Gyel columbite ore. $5.0 \mathrm{~kg}$ of the ore of sieve size $-1400+355 \mu \mathrm{m}$ representing the coarse sizes, $-355+90 \mu \mathrm{m}$ representing the medium sizes and $-90+45 \mu \mathrm{m}$ representing the fine sizes was charged into the hopper of the three disc rapid magnetic separating machine respectively and the shutter was opened slightly to allow even and gradual spread of the feed on the magnetic belt at a standard feed rate of $50 \mathrm{~kg} / \mathrm{hr}$, Disc height from the conveyor belt was adjusted to $10 \mathrm{~mm}$, and current applied was 20 Amperes (1.8 Tesla or 18.500 Gauss) [15]. The concentrate (i.e. columbite), tailing 1 (i.e. Iron) and Tailing 2 (Silica, Zircon and Tin minerals) were sampled out as the products and analyzed to ascertain their chemical compositions. Figure 1 illustrates the flowchart of the stage I: single process.

2) Gravity Concentration Method using Air-floating Method

$5 \mathrm{~kg}$ each of the ore sample of sieve sizes $-1400+355 \mu \mathrm{m},-355+90 \mu \mathrm{m}$ and $-90+45 \mu \mathrm{m}$ were fed to the hopper to the deck of the Pneumatic Kip Kelly Air-floating machine model MY-1151, size 300 at a feed rate of 50 kilograms per hour; with the air inlet opening at $2 \mathrm{~cm}$ and deck tilted at an angle of $0^{\circ}\left(180^{\circ}\right)$ [16] respectively. The products of the air floating table are concentrate, middling and tailing. The resulting middling was recycled to give concentrate and tailing as product. These products were sampled for analyses using ED-XRF. Figure 2 illustrate the flowchart of the stage I: single process.

\subsubsection{Phase II: Double Separation Methods}

1) Double Magnetic Separation Method (Rapid Magnetic to Rapid Magnetic)

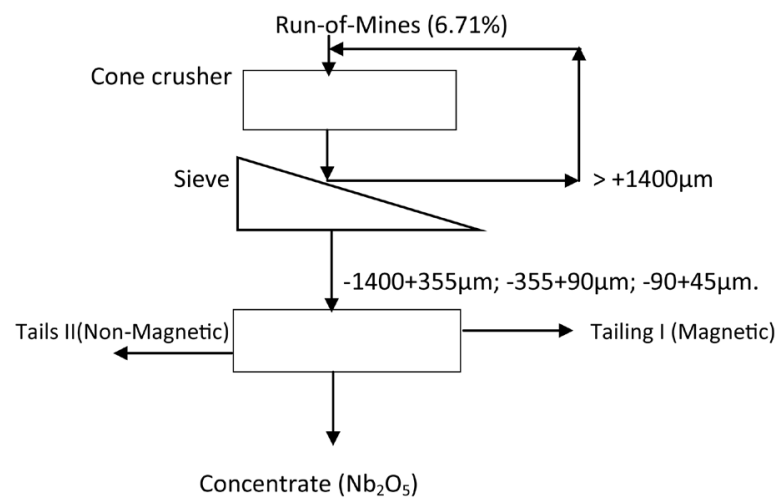

Figure 1. Flow chart illustrating the processing of Gyel columbite ore using Rapid Magnetic separator in stage I. 


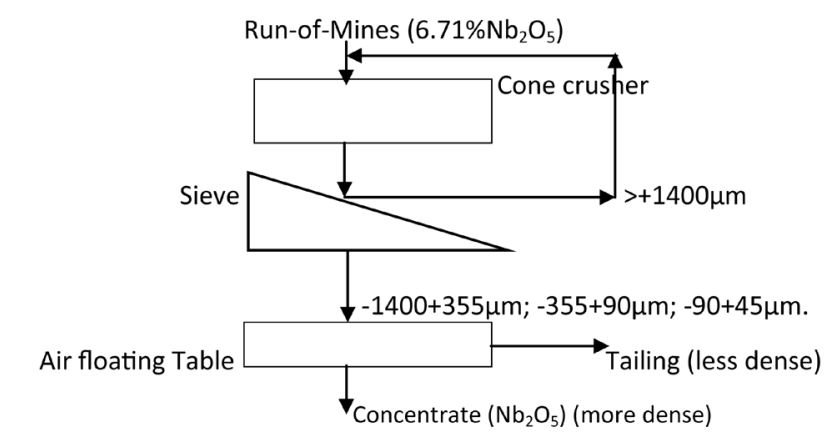

Figure 2. Flowchart illustrating the processing of Gyel columbite ore using Kip Kelly Air floating machine in stage I.

$1.07 \mathrm{~kg}, 1.21 \mathrm{Kg}, 1.04 \mathrm{Kg}$ of the Gyel columbite realized as pre-concentrate in the stage I single processes of sieve sizes $-1400+355 \mu \mathrm{m},-355+90 \mu \mathrm{m},-90+45 \mu \mathrm{m}$ respectively were rerun by charging into the hopper of Three disc high intensity rapid magnetic separator machine with the aim of achieving the stipulated standard of $50 \% \mathrm{Nb}_{2} \mathrm{O}_{5}$; the shutter was opened slightly to allow even and gradual spread of the feed (pre-concentrate) on the magnetic belt at a standard feed rate of $50 \mathrm{~kg} / \mathrm{hr}$, Disc height from the conveyor belt was adjusted to $10 \mathrm{~mm}$, and current applied was 20 Amperes (1.8 Tesla or 18.500 Gauss) [15]. The concentrate (i.e. columbite), middling 1 (i.e. Iron) and Tailing (Silica, Zircon and Tin minerals) were sampled out as the products and were analyzed to ascertain their chemical compositions. Figure 3 illustrates the flowchart of the process.

2) Air Floating Tabling Followed by Magnetic Process

Known weight of the pre-concentrate realized at stage I single process of the air floating process $(3.05 \mathrm{Kg}$; $3.39 \mathrm{Kg} ; 1.81 \mathrm{Kg}$ ) for sieve sizes $-1400+355 \mu \mathrm{m},-355+90 \mu \mathrm{m}$ and $-90+45 \mu \mathrm{m}$ were charged into three disc high intensity rapid magnetic separator respectively at standard conditions as earlier stated in stage I single process. The resulting products (concentrates and tailings) were weighed, sampled and analyzed for their chemical compositions. Figure 4: illustrates the flowchart of the process in double stage II.

The head sample and samples of the products i.e. both concentrates (paramagnetic) and tailing (magnetic and nonmagnetic) realized were properly weighed and sampled using random sampling method and analyzed for their chemical compositions at the Spectrum (Ferticore) Metals and Mineral Research Industries Limited, Taiwai Shatin, Hong Kong and Pictorial University in South Africa to ensure the certainty of the results.

\section{Results and Discussions}

\subsection{Chemical Analysis of the Head Sample of the Columbite Ore}

Figure 5(a) and Figure 5(b) (Table 1) present the result of the chemical analysis of columbite ore sample using $\mathrm{ED}$ - XRF. The result revealed that the ore sample contained $6.71 \% \mathrm{Nb}_{2} \mathrm{O}_{5}, 4.2 \% \mathrm{Al}_{2} \mathrm{O}_{3}, 27.0 \% \mathrm{SiO}_{2}, 23.1 \%$ $\mathrm{Fe}_{2} \mathrm{O}_{3}, 22.2 \% \mathrm{TiO}_{2}, 0.79 \% \mathrm{Ta}_{2} \mathrm{O}_{5}, 6.47 \% \mathrm{SnO}_{2}, 14.7 \% \mathrm{ZrO}_{2}$ and $1.01 \% \mathrm{MnO}$. Other compounds found in traces are $\mathrm{CaO}, \mathrm{V}_{2} \mathrm{O}_{5}, \mathrm{NiO}, \mathrm{HfO}, \mathrm{Rb}_{2} \mathrm{O}, \mathrm{Ag}_{2} \mathrm{O}, \mathrm{Au}, \mathrm{PbO}, \mathrm{Bi}_{2} \mathrm{O}_{3}, \mathrm{U}_{3} \mathrm{O}_{5}$, and $\mathrm{ThO}_{2}$. [6] [9]-[11] reported that most of the columbite mineral deposits in Plateau state and other places where intrusion of the younger granites are found contains niobium mineral in various proportions and vary from deposit to deposit depending on the geochemical composition of the minerals that formed the parent rock. The result obtained also indicated that the ore cannot be utilized directly in the furnace because of it low niobium content unless it is beneficiated to meet metallurgical required grade. This result obtained compared favourably with other deposits cited in the literatures and showcased the ore as another potential source of niobium, titanium manganese and zircon minerals as $1 \%-10 \%$ of such mineral can be added in steel as alloying elements [17].

\subsection{Concentration Tests}

\subsubsection{Single Stage Separation Methods}

1) Rapid Magnetic Separation Method

Figure 6(a) and Figure 6(b) (Table 2) present \% assays and recoveries of concentrates and tailings of the sample beneficiated using single stage process of magnetic concentration method for sieve size fractions of -1400 


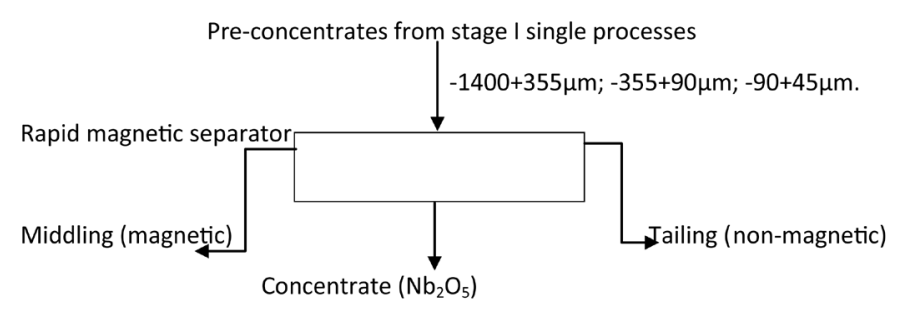

Figure 3. Flowchart illustrating double processing stage of Gyel columbite ore using three disc rapid magnetic followed by re-processing using rapid magnetic separation.

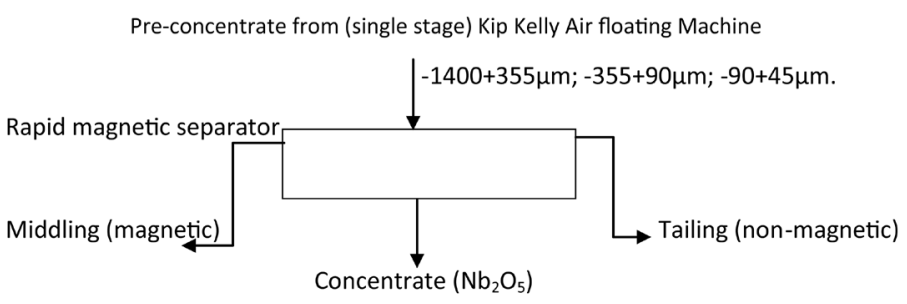

Figure 4. Flowchart illustrating double processing stages of Gyel columbite ore using Air floating followed by Rapid magnetic separation process.

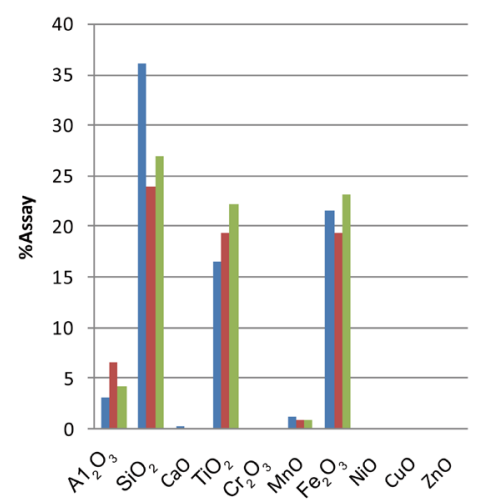

(a)

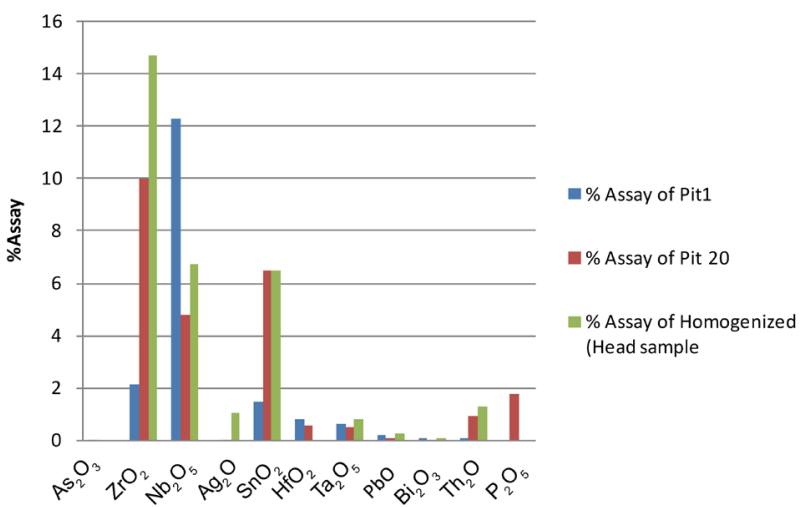

(b)

Figure 5. (a) and (b) Chemical composition of Gyel columbite head sample (Pit 1, Pit 20 and homogenized) using ED-XRF.

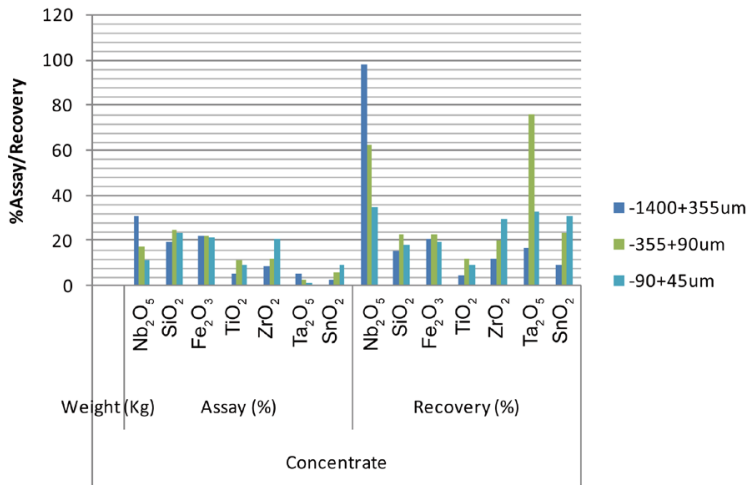

(a)

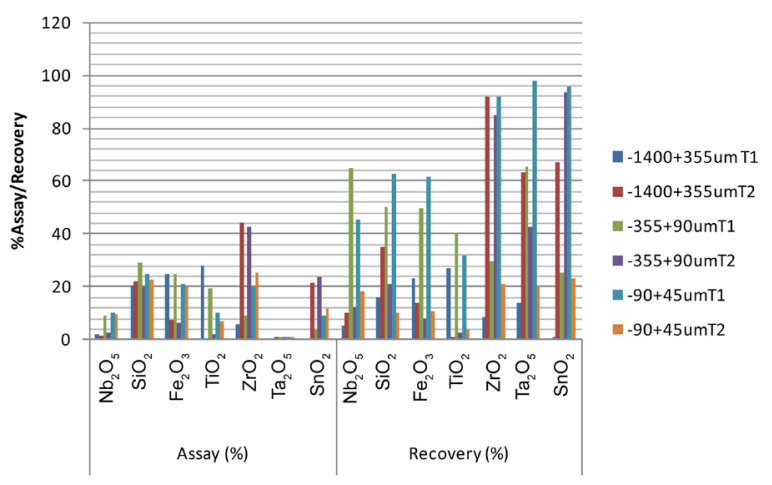

(b)

Figure 6. (a) \% Assay against sieve size fractions ( $\mu \mathrm{m})$ of single stage rapid magnetic separation method of Gyel columbite; (b) \% Recovery against Sieve size fractions $(\mu \mathrm{m})$ of single stage rapid magnetic process of Gyel columbite ore. 
Table 1. Result of the Chemical Composition of Gyel Columbite Head Sample for Pit 1, Pit 20 and homogenized using ED$\mathrm{XRF}$.

\begin{tabular}{|c|c|c|c|}
\hline $\begin{array}{l}\text { Chemical Compound } \\
\text { Composition }\end{array}$ & Assay of Sample from Pit $1(\%)$ & Assay of Sample from Pit $20(\%)$ & $\begin{array}{l}\text { Assay of Head Sample } \\
\text { (Homogenized) (\%) }\end{array}$ \\
\hline $\mathrm{Al}_{2} \mathrm{O}_{3}$ & 3.2 & 6.57 & 4.2 \\
\hline $\mathrm{SiO}_{2}$ & 36.1 & 23.96 & 27.0 \\
\hline $\mathrm{P}_{2} \mathrm{O}_{5}$ & - & 1.75 & - \\
\hline $\mathrm{K}_{2} \mathrm{O}$ & - & 0.64 & - \\
\hline $\mathrm{CaO}$ & 0.28 & 0.17 & 0.23 \\
\hline $\mathrm{TiO}_{2}$ & 16.5 & 19.36 & 22.2 \\
\hline $\mathrm{V}_{2} \mathrm{O}_{5}$ & 0.65 & 0.06 & 0.64 \\
\hline $\mathrm{Cr}_{2} \mathrm{O}_{3}$ & 0.24 & 0.07 & - \\
\hline $\mathrm{MnO}$ & 1.22 & 1.01 & 1.01 \\
\hline $\mathrm{Fe}_{2} \mathrm{O}_{3}$ & 21.6 & 19.34 & 23.1 \\
\hline $\mathrm{NiO}$ & 0.04 & 0.01 & 0.009 \\
\hline $\mathrm{CuO}$ & 0.093 & 0.01 & - \\
\hline $\mathrm{ZnO}$ & 0.10 & 0.09 & 0.099 \\
\hline $\mathrm{HfO}_{2}$ & 0.82 & 0.53 & - \\
\hline $\mathrm{AS}_{2} \mathrm{O}_{3}$ & 0.01 & - & - \\
\hline $\mathrm{Se}_{2} \mathrm{O}_{3}$ & - & 0.01 & - \\
\hline $\mathrm{Rb}_{2} \mathrm{O}$ & - & 0.02 & 0.051 \\
\hline $\mathrm{Y}_{2} \mathrm{O}_{3}$ & 0.34 & 0.83 & 1.42 \\
\hline $\mathrm{ZrO}_{2}$ & 2.11 & 9.96 & 14.7 \\
\hline $\mathrm{SnO}_{2}$ & 1.48 & 6.47 & 6.47 \\
\hline $\mathrm{Nb}_{2} \mathrm{O}_{5}$ & 12.26 & 4.78 & 6.71 \\
\hline $\mathrm{Ag}_{2} \mathrm{O}$ & - & 0.01 & 1.0 \\
\hline $\mathrm{EU}_{2} \mathrm{O}_{3}$ & 0.20 & 0.10 & - \\
\hline $\mathrm{Ta}_{2} \mathrm{O}_{5}$ & 0.62 & 0.49 & 0.79 \\
\hline $\mathrm{Yb}_{2} \mathrm{O}_{3}$ & 0.20 & 0.17 & - \\
\hline $\mathrm{WO}_{2}$ & - & 0.12 & 0.1 \\
\hline $\mathrm{Au}$ & 0.10 & - & 0.067 \\
\hline $\mathrm{PbO}$ & 0.19 & 0.09 & 0.22 \\
\hline $\mathrm{Bi}_{2} \mathrm{O}_{3}$ & 0.07 & 0.01 & 0.088 \\
\hline $\mathrm{U}_{3} \mathrm{O}_{5}$ & 0.22 & 0.11 & 0.15 \\
\hline $\mathrm{ThO}_{2}$ & 0.10 & 0.90 & 1.26 \\
\hline
\end{tabular}

$+355 \mu \mathrm{m}$ (coarse), $-355+90 \mu \mathrm{m}$ (semi-coarse) and $-90+45 \mu \mathrm{m}$ (Fine) respectively. From results presented for sieve size fractions of $-1400+355 \mu \mathrm{m}$, it was observed that the concentrate produced contains $30.64 \% \mathrm{Nb}_{2} \mathrm{O}_{5}$, 19.34\% $\mathrm{SiO}_{2}, 22.13 \% \mathrm{Fe}_{2} \mathrm{O}_{3}, 5.20 \% \mathrm{TiO}_{2}, 8.38 \% \mathrm{ZrO}_{2}, 5.19 \% \mathrm{Ta}_{2} \mathrm{O}_{5}$ and 2.88\% $\mathrm{SnO}_{2}$ with recoveries of $97.71 \%, 15.33 \%, 20.50 \%, 5.00 \%, 12.20 \%, 16.55 \%$ and $9.19 \%$ for the respective mineral compounds. Sieve size 
Table 2. Metallurgical Balance for single and double stage magnetic separation method.

\begin{tabular}{|c|c|c|c|c|c|c|c|c|c|}
\hline \multicolumn{10}{|c|}{ Single Stage : Magnetic Separation } \\
\hline & \multicolumn{3}{|c|}{ Weight of Ore (Kg) } & \multicolumn{3}{|c|}{ Assay of $\mathrm{Nb}_{2} \mathrm{O}_{5}(\%)$} & \multicolumn{3}{|c|}{$\%$ Recovery } \\
\hline & $\begin{array}{c}-1400+355 \\
\mu \mathrm{m}\end{array}$ & $\begin{array}{c}-355+90 \\
\mu \mathrm{m}\end{array}$ & $\begin{array}{c}-90+45 \\
\mu \mathrm{m}\end{array}$ & $\begin{array}{c}-1400+355 \\
\mu \mathrm{m}\end{array}$ & $-355+90 \mu \mathrm{m}$ & $-90+45 \mu \mathrm{m}$ & $\begin{array}{c}-1400+355 \\
\mu \mathrm{m}\end{array}$ & $\begin{array}{c}-355+90 \\
\mu \mathrm{m}\end{array}$ & $-90+45 \mu \mathrm{m}$ \\
\hline Feed $_{1}$ & 5.0 & 5.0 & 5.0 & 6.71 & 6.71 & 6.71 & - & - & - \\
\hline Conc $_{1}$ & 1.07 & 1.21 & 1.04 & 30.67 & 17.23 & 11.15 & 97.71 & 62.47 & 34.56 \\
\hline Tailing 1 & 1.80 & 2.33 & 3.64 & 1.62 & 9.37 & 4.11 & 5.21 & 65.07 & 45.32 \\
\hline Tailing 2 & 2.13 & 1.46 & 0.32 & 1.59 & 2.83 & 9.96 & 10.09 & 12.32 & 18.41 \\
\hline \multicolumn{10}{|c|}{ Double Stage: Magnetic-to-Magnetic Separation } \\
\hline Feed $_{2}$ & 1.07 & 1.21 & 1.04 & 30.67 & 17.23 & 11.15 & - & - & - \\
\hline Conc $_{2}$ & 0.547 & 0.260 & 0.155 & 52.12 & 34.32 & 15.18 & 86.96 & 42.80 & 20.29 \\
\hline Tailing 1 & 0.254 & 0.490 & 0.849 & 10.71 & 0.790 & 8.57 & 8.30 & 41.86 & 62.75 \\
\hline Tailing 2 & 0.269 & 0.460 & 0.036 & 7.86 & 0.460 & 5.49 & 6.45 & 1.74 & 1.70 \\
\hline
\end{tabular}

fractions of $-355+90 \mu \mathrm{m}$ concentrate produced contains $17.23 \% \mathrm{Nb}_{2} \mathrm{O}_{5}, 25.13 \% \mathrm{SiO}_{2}, 21.95 \% \mathrm{Fe}_{2} \mathrm{O}_{3}, 11.07 \%$ $\mathrm{TiO}_{2}, 12.14 \% \mathrm{ZrO}_{2}, 2.48 \% \mathrm{Ta}_{2} \mathrm{O}_{5}$ and $2.88 \% \mathrm{SnO}_{2}$ with recoveries of $62.47 \%, 22.52 \%, 23.09 \%, 12.07 \%, 19.98 \%$, $75.95 \%$ and $23.46 \%$ for the respective mineral compounds. Sieve size fractions of $-90+45 \mu \mathrm{m}$ concentrate produced contains $11.15 \% \mathrm{Nb}_{2} \mathrm{O}_{5}, 23.19 \% \mathrm{SiO}_{2}, 21.51 \% \mathrm{Fe}_{2} \mathrm{O}_{3}, 9.70 \% \mathrm{TiO}_{2}, 21.07 \% \mathrm{ZrO}_{2}, 1.26 \% \mathrm{Ta}_{2} \mathrm{O}_{5}$ and $9.52 \% \mathrm{SnO}_{2}$ with recoveries of $34.56 \%, 17.86 \%, 19.37 \%, 9.09 \%, 29.81 \%, 33.17 \%$ and $30.61 \%$ for the respective mineral compounds. Comparing the results of the test, sieve size fractions of $-1400+355 \mu \mathrm{m}$ concentrate has the highest content of $30.64 \% \mathrm{Nb}_{2} \mathrm{O}_{5}$ and a recovery of $97.71 \%$ when compared to the niobium contents and recoveries of sieve size fractions of $-355+90 \mu \mathrm{m}$ and $-90+45 \mu \mathrm{m}$. This could be attributed to the particle size factor of the niobium minerals, which at coarse particle sizes the niobium minerals are not completely liberated from the associated minerals like iron. Hence, the tendency for the niobium minerals at the coarsest sizes to be magnetize into the concentrate. Further observation reveals that as the particle size reduce the percent niobium content and recovery decreased. Weiss [18]-[20] [3] have reported that niobium mineral is non-magnetic in nature. Therefore phenomenon observed above could be ascribed to the reason that as the particle of the niobium minerals reduces, the minerals are liberated from the associated iron minerals and hence the effect of magnetic attraction on the niobium mineral is reduced visa-vi it reduction in \%assay content and recovery. For the tailings, insignificant percentage of niobium mineral for all the sieves size fractions was recorded, but much of the $\mathrm{SnO}_{2}$ mineral was found to be present in the tailings. Subjecting the tailings to magnetic separation, $\mathrm{SnO}_{2}$ assaying $23.74 \%$ and a recovery of $93.39 \%$ at $-355+90 \mu \mathrm{m}$ was obtained.

2) Single Stage Air Floatation Separation Method

From the results presented in Figure 7(a) and Figure 7(b) (Table 3), it can be observed sieve size fractions of $-355+90 \mu \mathrm{m}$ concentrate contains $12.14 \% \mathrm{Nb}_{2} \mathrm{O}_{5}, 22.14 \% \mathrm{SiO}_{2}, 22.41 \% \mathrm{Fe}_{2} \mathrm{O}_{3}, 11.57 \% \mathrm{TiO}_{2}, 16.72 \% \mathrm{ZrO}_{2}$, $1.40 \% \mathrm{Ta}_{2} \mathrm{O}_{5}$ and $10.65 \% \mathrm{SnO}_{2}$ with recoveries of $98.60 \%, 55.60 \%, 65.77 \%, 35.23 \%, 77.12 \%, 98.21 \%$ and $91.16 \%$ for the respective mineral compounds. Sieve size fractions of $-90+45 \mu \mathrm{m}$ concentrate contains $11.37 \%$ $\mathrm{Nb}_{2} \mathrm{O}_{5}, 24.03 \% \mathrm{SiO}_{2}, 21.37 \% \mathrm{Fe}_{2} \mathrm{O}_{3}, 10.52 \% \mathrm{TiO}_{2}, 18.31 \% \mathrm{ZrO}_{2}, 1.20 \% \mathrm{Ta}_{2} \mathrm{O}_{5}$ and 9.30\% $\mathrm{SnO}_{2}$ with recoveries of $61.34 \%, 32.22 \%, 33.49 \%, 17.15 \%, 45.09 \%, 54.99 \%$ and $52.03 \%$ for the respective mineral compounds. Sieve size fractions of $-1400+355 \mu \mathrm{m}$ concentrate contains $10.77 \% \mathrm{Nb}_{2} \mathrm{O}_{5}, 19.84 \% \mathrm{SiO}_{2}, 25.70 \% \mathrm{Fe}_{2} \mathrm{O}_{3}, 13.99 \%$ $\mathrm{TiO}_{2}, 13.61 \% \mathrm{ZrO}_{2}, 1.27 \% \mathrm{Ta}_{2} \mathrm{O}_{5}$ and $12.02 \% \mathrm{SnO}_{2}$ with recoveries of $97.91 \%, 44.80 \%, 67.87 \%, 38.44 \%$, $56.48 \%, 96.06 \%$ and $93.33 \%$ for the respective mineral compounds. Comparing the results of the test, $-355+90$ $\mu \mathrm{m}$ sieve size fractions has the highest percentage of niobium mineral content and recovery when compared $-90+$ $45 \mu \mathrm{m}$ and $-1400+355 \mu \mathrm{m}$. The reason for this phenomenon could be that the niobium mineral contain in $-355+$ $90 \mu \mathrm{m}$ has attained it critical particle size factor that produced the required density of the mineral needed to be lifted by the air streams to enable its separation and migration into the concentrate. Reversed of this phenomenon could be responsible for low contents and recoveries values of niobium mineral in the $-90+45 \mu \mathrm{m}$ and $-1400+$ 


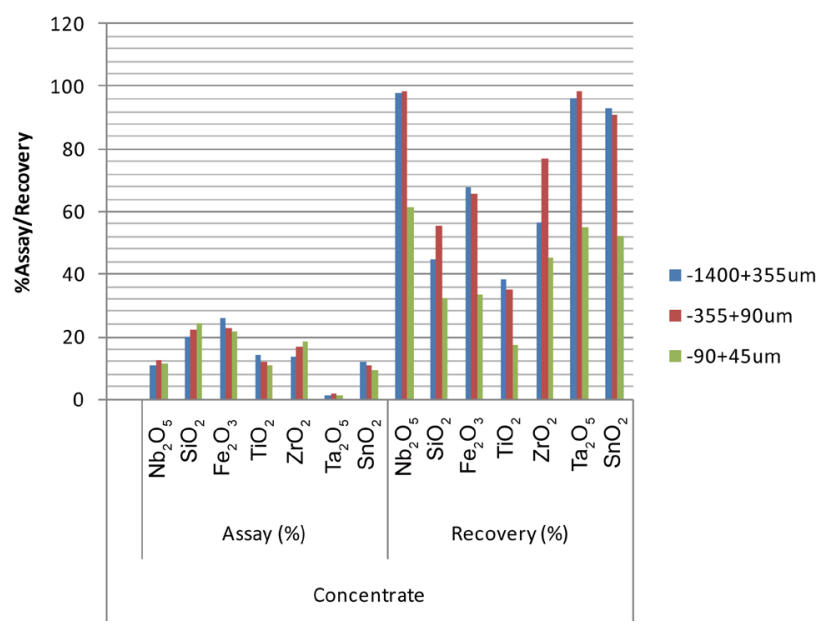

(a)

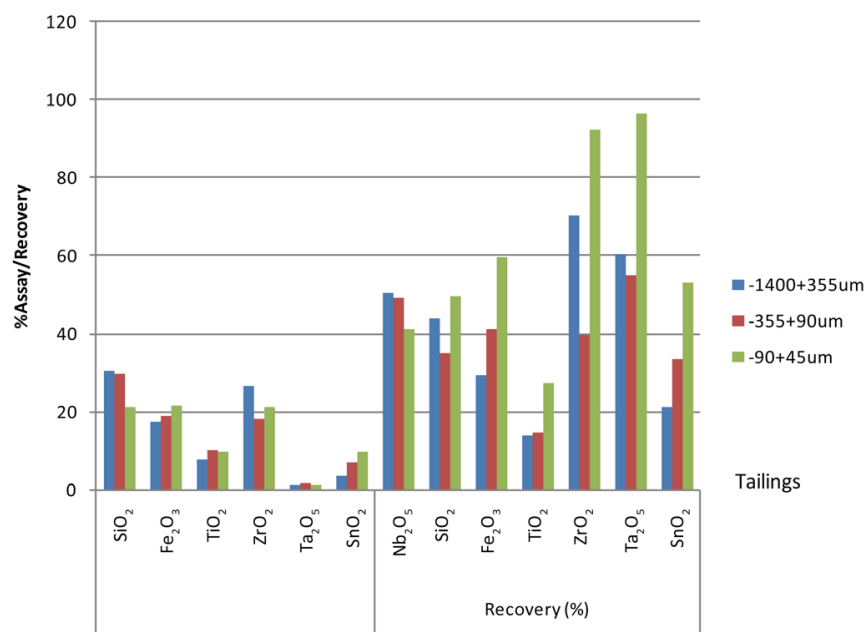

(b)

Figure 7. (a) \% Assay/Recovery against Sieve size fraction $(\mu \mathrm{m})$ of single stage Air floatation separation process of Gyel columbite; (b) \% Assay/recovery against Sieve size fraction $(\mu \mathrm{m})$ of single stage Air Floatation separation process of Gyel columbite.

Table 3. Metallurgical Balance for single and double stage Air Floatation separation method.

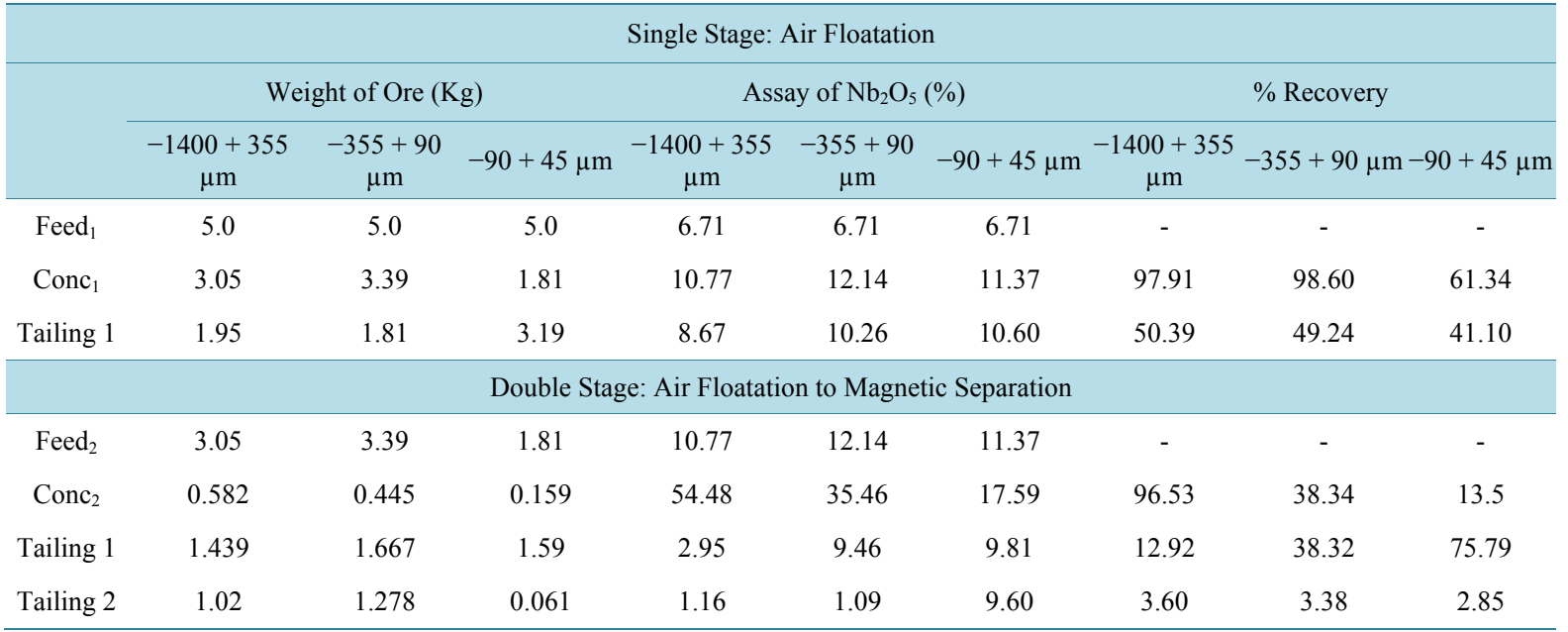


$355 \mu \mathrm{m}$ sieves size fractions [1] [18]. For the tailings results significant percent content of the niobium mineral was observed to be contained in the various sieve size fractions, but with poor recoveries values when compared to that of the concentrates. This trend reveals that the niobium minerals do not respond effectively to the separation process of the air floatation when compared to the rapid magnetic separation method. Reason been that [18] [21] have reported in different forum, that critical size factor of a particle is a very important parameter that if attained, particles of minerals will respond to the effect of the mechanism use to separate or agglomerate the particles. Hence, the above stated condition is not made by the mineral particles of the various sieves size fractions and thus, the poor response to the separation test of the air floatation separation method. From the tests conducted using the single stage processes, none of the processes used in the single stage produces the required grade of $50 \% \mathrm{Nb}_{2} \mathrm{O}_{5}$ concentrates stipulated as metallurgical standard by the smelting industry. This necessitated the used of the double stage processes to see if the required grade of concentrates could be produced.

\subsubsection{Double Stage Separation Tests}

1) Rapid Magnetic to Rapid Magnetic Separation Method (Double Stage Rapid Magnetic Separation Method)

Figure 8(a) and Figure 8(b) (Table 2) present the results of the double stage rapid magnetic separation method of the ore sample. From the results it can be observed that sieve size fractions of $-1400+355 \mu \mathrm{m}$ produced a concentrate assaying $52.12 \% \mathrm{Nb}_{2} \mathrm{O}_{5}, 10.40 \% \mathrm{SiO}_{2}, 14.27 \% \mathrm{Fe}_{2} \mathrm{O}_{3}, 4.41 \% \mathrm{TiO}_{2}, 8.41 \% \mathrm{ZrO}_{2}, 5.71 \% \mathrm{Ta}_{2} \mathrm{O}_{5}$ and

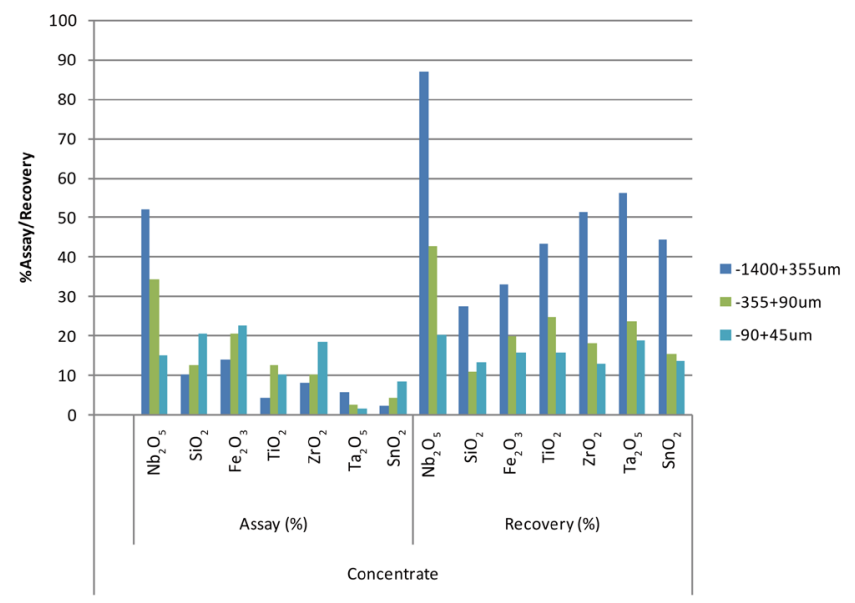

(a)

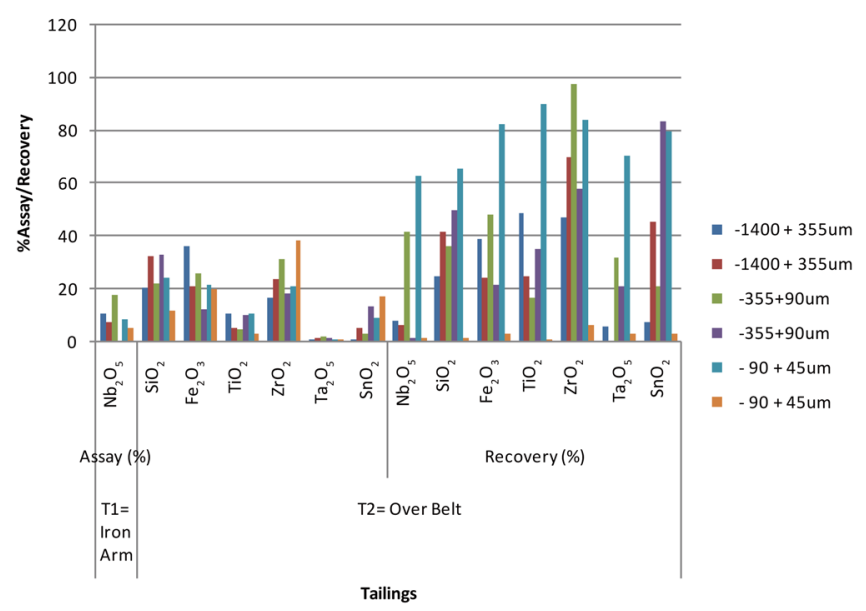

(b)

Figure 8. (a) \% Assay/Recovery against Sieve size fraction $(\mu \mathrm{m})$ of double stage magnetic process of Gyel columbite ore at various sieve size fractions; (b) \% Assay/Recovery against Sieve size fraction $(\mu \mathrm{m})$ of double stage magnetic process of Gyel columbite ore at various sieve size fractions. 
$2.50 \% \mathrm{SnO}_{2}$ with recoveries of $86.96 \%, 27.49 \%, 32.96 \%, 43.35 \%, 51.30 \%, 56.24 \%$ and $44.38 \%$ for the respective mineral compounds. Sieve size fractions of $-355+90 \mu \mathrm{m}$ concentrate produced contains $34.32 \% \mathrm{Nb}_{2} \mathrm{O}_{5}, 12.79 \%$ $\mathrm{SiO}_{2}, 20.60 \% \mathrm{Fe}_{2} \mathrm{O}_{3}, 12.78 \% \mathrm{TiO}_{2}, 10.26 \% \mathrm{ZrO}_{2}, 2.75 \% \mathrm{Ta}_{2} \mathrm{O}_{5}$ and $4.50 \% \mathrm{SnO}_{2}$ with recoveries of $42.80 \%$, $10.94 \%, 20.17 \%, 24.81 \%, 18.16 \%, 23.83 \%$ and $15.42 \%$ for the respective mineral compounds. Sieve size fractions of $-90+45 \mu \mathrm{m}$ concentrate produced contains $15.18 \% \mathrm{Nb}_{2} \mathrm{O}_{5}, 20.67 \% \mathrm{SiO}_{2}, 22.79 \% \mathrm{Fe}_{2} \mathrm{O}_{3}, 10.28 \% \mathrm{TiO}_{2}$, $18.63 \% \mathrm{ZrO}_{2}, 1.61 \% \mathrm{Ta}_{2} \mathrm{O}_{5}$ and $8.79 \% \mathrm{SnO}_{2}$ with recoveries of $20.29 \%, 13.33 \%, 15.79 \%, 15.80 \%, 13.18 \%$, $19.04 \%$ and $13.76 \%$ for the respective mineral compounds. Comparing the results, sieve size fractions of $-1400+$ $355 \mu \mathrm{m}$ concentrate has the highest content of $52.12 \% \mathrm{Nb}_{2} \mathrm{O}_{5}$ and a recovery of $86.96 \%$ when compared to the niobium contents and recoveries of sieve size fractions of $-355+90 \mu \mathrm{m}$ and $-90+45 \mu \mathrm{m}$. The reason for the high content of the niobium mineral could be attributed to the reduction in iron; titanite and others associated minerals proportions in the concentrate of the double stage rapid magnetic separation method produced. Furthermore the trend is facilitated by under grinding of the columbite ore which exited the liberation of the niobium minerals and subsequently the migration of the niobium mineral into the concentrate and the un-liberated ones lost to the tailing alongside other associated minerals contain in the pre-concentrate. It has also been reported that under-grinding or over grinding of minerals do excite the minerals contain in a feed to be liberated [3]. Hence, this phenomenon gave rise to the high proportion of niobium mineral $\left(52.12 \% \mathrm{Nb}_{2} \mathrm{O}_{5} ; 86.96 \%\right.$ recovery) in the concentrate when compared to the assay contents of other minerals of the same sieve size fractions; and also when compared to the other sieves size fractions subjected to the same test. The assay of niobium mineral obtained for this test met the $50.00 \%$ $\mathrm{Nb}_{2} \mathrm{O}_{5}$ assay content stated as metallurgical standard required by metallurgical smelting company. For the result of the tailings produced, $10.71 \% \mathrm{Nb}_{2} \mathrm{O}_{5}$ mineral content is lost to tailing1 with a recovery of $8.30 \%$ and $7.86 \%$ $\mathrm{Nb}_{2} \mathrm{O}_{5}$ is also lost to tailing 2 with a recovery of $6.45 \%$ the reason for this, has been earlier stated above. Therefore the assay contents of the niobium mineral lost to tailing 1 and 2 are insignificant and can be recovered through scavenging/re-cleaning of the tailings (Weiss, 1985).

2) Double Stage: Air Floatation Followed by Rapid Magnetic Concentration Method

Figure 9(a) and Figure 9(b) (Table 3) present the results of the double stage air-loatation followed by rapid magnetic separation method. From the results it can be observed that sieve size fractions of $-1400+355 \mu \mathrm{m}$ produced a concentrate assaying $54.48 \% \mathrm{Nb}_{2} \mathrm{O}_{5}, 16.39 \% \mathrm{SiO}_{2}, 10.46 \% \mathrm{Fe}_{2} \mathrm{O}_{3}, 6.10 \% \mathrm{TiO}_{2}, 1.14 \% \mathrm{ZrO}_{2}, 6.28 \%$ $\mathrm{Ta}_{2} \mathrm{O}_{5}$ and $3.47 \% \mathrm{SnO}_{2}$ with recoveries of $96.53 \%, 15.76 \%, 7.77 \%, 8.32 \%, 1.59 \%, 94.35 \%$ and $5.51 \%$ for the respective mineral compounds. $-355+90 \mu \mathrm{m}$ concentrate produced contains $35.46 \% \mathrm{Nb}_{2} \mathrm{O}_{5}, 12.29 \% \mathrm{SiO}_{2}$, $21.09 \% \mathrm{Fe}_{2} \mathrm{O}_{3}, 10.51 \% \mathrm{TiO}_{2}, 11.38 \% \mathrm{ZrO}_{2}, 6.28 \% \mathrm{Ta}_{2} \mathrm{O}_{5}$ and $3.28 \% \mathrm{SnO}_{2}$ with recoveries of $38.34 \%, 7.29 \%$, $12.34 \%, 11.92 \%, 8.94 \%, 58.88 \%$ and $4.04 \%$ for the respective mineral compounds. $-90+45 \mu$ m concentrate produced contains $17.59 \% \mathrm{Nb}_{2} \mathrm{O}_{5}, 19.49 \% \mathrm{SiO}_{2}, 18.85 \% \mathrm{Fe}_{2} \mathrm{O}_{3}, 10.72 \% \mathrm{TiO}_{2}, 19.19 \% \mathrm{ZrO}_{2}, 1.43 \% \mathrm{Ta}_{2} \mathrm{O}_{5}$ and $8.78 \% \mathrm{SnO}_{2}$ with recoveries of $13.59 \%, 7.12 \%, 7.75 \%, 8.95 \%, 9.21 \%, 10.47 \%$ and $8.29 \%$ for the respective mineral compounds. Comparing the results, sieve size fractions of $-1400+355 \mu \mathrm{m}$ concentrate has the highest content of $54.48 \% \mathrm{Nb}_{2} \mathrm{O}_{5}$ and a recovery of $96.53 \%$ when compared to the niobium contents and recoveries of sieve size fractions of $-355+90 \mu \mathrm{m}$ and $-90+45 \mu \mathrm{m}$. This is attributed to the reduction in iron, titanite and other associated minerals contents in the concentrate that is created by grinding condition which excited the liberation of the niobium minerals and their subsequent migration into the concentrate. While the un-liberated, are lost to the tailing alongside other associated minerals contain in the pre-concentrate that served as a feed to the double stage process. [3] [18] [22] have also observed similar trends like the one above and reported such. Another reason could be due to that, $-1400+355 \mu \mathrm{m}$ sieve size fractions niobium mineral are more exposed to magnetic effect than other minerals that have fine particles sizes [14] and probably most of the dust and other hindering impurities might have been discarded in the single stage process making the double stage process to serve as a re-cleaning mechanism as reported by Falcon [23]. This phenomenon enhances the high in proportion of niobium mineral (54.48\% $\mathrm{Nb}_{2} \mathrm{O}_{5} ; 96.53 \%$ recovery) in the concentrate when compared to the assay contents of other minerals in the same sieve size fractions and also when compared to the other sieves size fractions subjected to the same test. The assay of niobium mineral obtained for this test surpassed the $50.00 \% \mathrm{Nb}_{2} \mathrm{O}_{5}$ assay content stated as metallurgical standard required by metallurgical smelting company. For the results of tailings produced, $2.95 \% \mathrm{Nb}_{2} \mathrm{O}_{5}$ mineral content is lost to tailing 1 with a recovery of $12.92 \%$, and $1.16 \% \mathrm{Nb}_{2} \mathrm{O}_{5}$ also lost to tailing 2 with a recovery of $3.60 \%$. The reason for this, has been earlier been explained above.

From all the double stage tests carried out on the various sieves size fractions of the Gyel columbite sample. The test of double stage: air-floatation followed by rapid magnetic separation method for sieve size fractions of -1400 $+355 \mu \mathrm{m}$ produced concentrate assaying $54.48 \% \mathrm{Nb}_{2} \mathrm{O}_{5}$ and a recovery of $96.53 \%$ when compared to double 


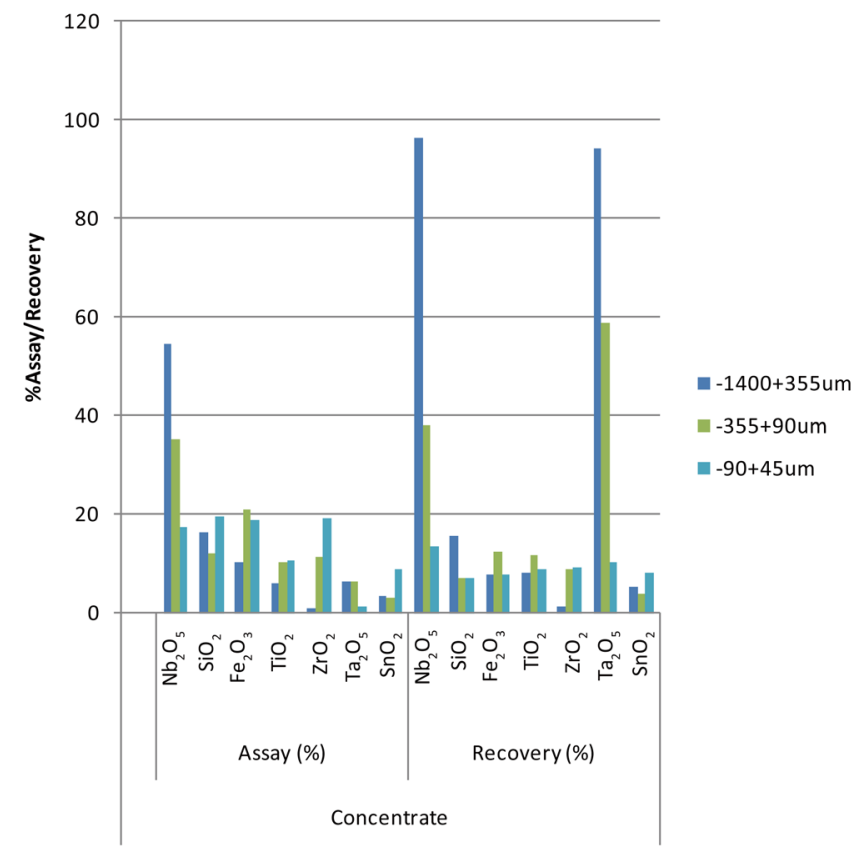

(a)

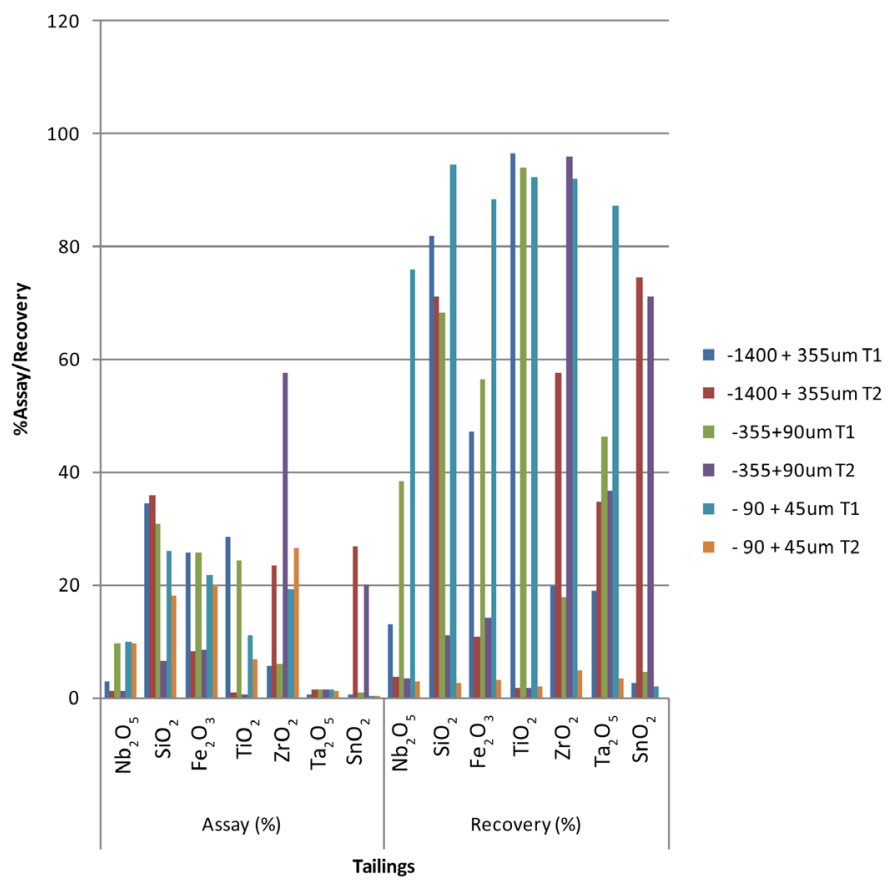

(b)

Figure 9. (a) \% Assay against Sieve size fraction $(\mu \mathrm{m})$ of double stage air floatation followed by magnetic separation process of columbite at various sieve size fractions; (b) $\%$ Assay/Recovery against Sieve size fraction $(\mu \mathrm{m})$ of double stage air floatation followed by magnetic separation process of columbite at various sieve size fractions.

stage rapid magnetic to rapid magnetic separation method which produced concentrate assaying $52.12 \% \mathrm{Nb}_{2} \mathrm{O}_{5}$ and recovery of $86.96 \%$ for the same sieve size fractions. These processes produced concentrates which assay contents are higher and surpasses the $50.00 \% \mathrm{Nb}_{2} \mathrm{O}_{5}$ content required as standard for metallurgical smelting. On the basis of these findings the optimum processing methods for the columbite ore using the double stage separa- 
tion methods is the air-floatation/rapid magnetic followed by the rapid magnetic/rapid magnetic separation methods.

\section{Conclusions}

The comparative beneficiation study of Gyel columbite ore using double stage (magnetic-to-magnetic and magnetic-to-gravity) to metallurgical grade has been carried out and conducted in two phases. The first stage involved the determination of the chemical compositions of the head sample to ascertain its chemical quality. The second stage involved carrying out concentration tests using mineral processing techniques of magnetic, gravity and the combination of the two techniques. From the results obtained the following conclusions were drawn as follows:

1) The chemical composition characterization reveals that the ore contains $6.71 \% \mathrm{Nb}_{2} \mathrm{O}_{5}, 4.20 \% \mathrm{Al}_{2} \mathrm{O}_{3}$, $27.0 \% \mathrm{SiO}_{2}, 23.1 \% \mathrm{Fe}_{2} \mathrm{O}_{3}, 22.2 \mathrm{TiO}_{2}, 0.79 \% \mathrm{Ta}_{2} \mathrm{O}_{5}, 6.47 \% \mathrm{SnO}_{2}, 14.7 \% \mathrm{ZrO}_{2}$ and $1.01 \% \mathrm{MnO}$. Other trace compounds found in the ore sample are $\mathrm{CaO}, \mathrm{V}_{2} \mathrm{O}_{5}, \mathrm{NiO}, \mathrm{HfO}, \mathrm{Rb}_{2} \mathrm{O}, \mathrm{Ag}_{2} \mathrm{O}, \mathrm{Au}, \mathrm{PbO}, \mathrm{Bi}_{2} \mathrm{O}_{3}, \mathrm{U}_{3} \mathrm{O}_{5}$, and $\mathrm{ThO}_{2}$.

2) The chemical analyses results of the products of the concentration tests conducted in the second phase single stage processing could not meet the stipulated metallurgical standard. Furthermore, it could be observed that the single stage rapid magnetic separation method is the optimum method when compared to the gravity (airfloatation) method. The optimum single method produced concentrate assaying $30.67 \% \mathrm{Nb}_{2} \mathrm{O}_{5}$ at sieve size fractions of $-1400+355 \mu \mathrm{m}$ which failed to meet the stipulated metallurgical standard, hence necessitated the need for the second phase of double stage processing to upgrade the pre-concentrates to meet the stipulated standard of $50 \% \mathrm{Nb}_{2} \mathrm{O}_{5}$.

3) The concentration test using the double stage processes reveals that the air-floatation followed by rapid magnetic method produced a concentrate with the highest percent assay of $54.48 \% \mathrm{Nb}_{2} \mathrm{O}_{5}$ and a recovery of $96.53 \%$ followed by the rapid-to-rapid magnetic method which produced a concentrate assaying $52.12 \% \mathrm{Nb}_{2} \mathrm{O}_{5}$ with a recovery of $86.96 \%$. These grades of concentrates produced surpass the stipulated grade of the concentrate required as metallurgical standard by the smelting industry.

\section{References}

[1] Maurice, C.F. and Kenneth, N. (2003) Principle of Mineral Processing. Society of Mining, Metallurgy, and Exploration, Inc. (SME), Georgia, 245-299.

[2] Apan, F.F. (1989) Gravity Concentration. In: Weiss, N.L., Ed., SME Mineral Processing Hand-Book, AIME, New York, 62-98.

[3] Wills, B.A. (2006) Mineral Processing Technology, 6th Edition, Pergamo Press, Oxford.

[4] Venkatraman, P., Knoll, F.S. and Lawver, J.E. (2003) Magnetic and Electrostatic Separation. In: Fuestenua, M.C. and Kenneth, N., Eds., Mineral Processing, Chap. 7, Wiley, New York, 221-243.

[5] Everistus, N. (2010) Niobium Ore Mining and Processing in Nigeria: The Opportunities. Nigeria Business Place, Abuja, 1-3.

[6] Ogbonna, A.I., Nwakaudu, S.M. and Onyemobi, O.O. (1999) Strategic Mineral Deposits in Nigeria (The Neglected Case of Niobotantalites). Proceedings of 16th Nigerian Metallurgical Society Annual Conference, Abuja, October $1999,67-75$.

[7] Fisher, R.G. (2011) Niobium Raw Materials and Processing. www.yourdictionary.com.2010 http//mineral.usgs.gov/minerals/pubs/commodity/niobium/

[8] Yaro, S.A. (1997) Development of Process Route for the Beneficiation of Mallam Ayuba Manganese Deposit to Ferromanganese Feed Grade. PhD Thesis, A.B.U., Zaria, Unpublished.

[9] Thomas, D.G., Asuke, F. and Yaro, S.A. (2014) Determination of Some Conceptual Mineral Processing Parameters of Soba-Wanka Pyrochlore-Coltan Mineral Ore Deposit. Proceedings of the Nigeria Engineering Conference, Faculty of Engineering, Ahmadu Bello University, Zaria, 827-841.

[10] Abdulrazaq, Y. (2014) Determination of Chemical, Mineralogical and Work Index of Soba-Wanka Mineral Ore Deposit. Department of Metallurgical and Materials Engineering Undergraduate Project, Unpublished.

[11] Htwe, H.H. and Lwin, K.T. (2008) Study on Extraction of Niobium Oxide from Columbite-Tantalite Concentrate. World Academy of Science, Engineering and Technology, 2, 10-27.

[12] Mallo, S.J. (2007) Minerals and Mining on the Jos, Plateau. ACON, Plateau State, Nigeria.

[13] Ayeni, F.A., Alabi, O.O. and Ola, S.O. (1999) Beneficiation of Tailings. Proceedings of the 16th Nigerian Metallur- 
gical Society Annual Conference, Abuja, 3-5 November 1999, 67-75.

[14] Ayeni, F.A., Madugu, I.A., Sukop, P., Ibitoye, S.A., Adeleke, A.A. and Abdulwahab, M. (2012) Secondary Recovery of Columbite from Tailing Dump in Nigerian Jos Mines Field. Journal of Minerals and Materials Characterization and Engineering, 11, 587-595. http://dx.doi.org/10.4236/jmmce.2012.116042

[15] Bronkala, W.J., Haskin, R.J., Tenpas, E.J. and Lawver, J.J. (1986) Types of Magnetic Separators. In: Society of Mining, Metallurgy and Exploration, Mineral Processing Handbook (SME), SME Inc., Colorado, 629-645.

[16] Taggart, A.F. (1987) Hand Book of Mineral Dressing. Section II, John Willey and Sons, New York, 11-55.

[17] Kudrin, V. (1985) Steel Making. Mir Publishers, Moscow.

[18] Weiss, N.L. (1985) Mineral Processing Handbook. American Institute of Mining Metallurgical and Petroleum Engineering Inc., Kings Port Press, USA.

[19] Harrison, H.L.H. (1962) Alluvial Mining of Tin and Gold. Chap. 6, Mining Publications, London, 119-141.

[20] Jones, H. (1987) The Separation of Strongly Magnetic Particles Particularly Those of Small Dimension. Proceedings of the 7th International Mineral Processing Congress, Vol. 1, Gordon and Breach, New York.

[21] Zainab, S.A. and Thomas, D.G. (2012) The Effect of Particle Size on the Characteristics of Pellets Produced from Calcined Koton Karfe Iron Ore. Nigerian Journal of Engineering, 18, 110-117.

[22] Klima, M. (2010) Mineral Processing. The Pennsylvania State University, University Park.

[23] Falcona, W. (1999) The Scientific Fundamental of Gravity, Mineral Processing Bulletin. Principle of Mineral Processing (AIME), September 2003. 